\title{
LONG-TERM CHANGES OF MACROPHYTOBENTHOS OF «SUDZHUK LAGOON» NATURAL MONUMENT (BLACK SEA)
}

\author{
Natalya S. Berezenko', Nataliya A. Milchakova² \\ ${ }^{1}$ Admiral F.F. Ushakov State Maritime University, Russia \\ e-mail:n-berezenko6753@rambler.ru \\ ${ }^{2}$ A.O. Kovalevsky Institute of Marine Biological Research of RAS, Russia \\ e-mail:milchakova@gmail.com
}

Received: 06.04.2018

\begin{abstract}
The Sudzhuk Lagoon, including Sudzhuk Spit and the adjacent territory, is a unique natural complex of the northeastern part of the Black Sea, that has been studied throughout the last century. In accordance with the environmental importance of lagoon ecosystems, the «Sudzhuk Lagoon» Natural Monument of regional significance was created in 1983, which was included within the network of Protected Areas of the Krasnodarsky Krai. The goal of the present research was to characterise the long-term changes in lagoon's bottom vegetation from 1921 to 2015, and to reveal the features of species composition and the communities changes. During the investigation period, the number of macrophyte species increased from 16 to 27. Five new species typical for eutrophic water have been found, and more than ten species disappeared. Despite the Sudzhuk Lagoon being included within the protected areas, almost a complete disappearance of the Lamprothamnium papulosum + Chara vulgaris community and a dominance of the Ruppia cirrhosa-Lophosiphonia obscura-Cladophora albida community have been observed. By 2015, the biomass of the opportunistic green alga Ulva intestinalis near the channel, which connect the lagoon with the sea, increased by an order of magnitude compared to 1985. At the present time, intensive transformation has occurred in communities of aquatic vegetation, and the dominance of Phragmites australis and Stuckenia pectinata were found. Almost all research areas of the Sudzhuk Lagoon were in a poor ecological status according to the Ecological Index (EI), except for a few locations in the central and southeastern parts with a moderate ecological status. The lack of a management plan to protect the Sudzhuk Lagoon and intensification of unregulated recreation, along with other natural and anthropogenic factors, can lead to the loss of this unique natural complex. Effective measures aiming at preserving the ecosystem of the Sudzhuk Lagoon with its biological and landscape diversity were proposed.
\end{abstract}

Key words: biomass, Charophyta, ecological status, long-term monitoring, macrophytes, species composition

\section{Introduction}

The Sudzhuk Lagoon and Sudzhuk Spit form a single semi-isolated seaside natural complex in the northeastern part of the Black Sea, near Novorossiysk Bay. It plays a significant role for commercial fish species feeding and spawning, conservation of waterfowl habitats during their migrations and wintering, as well as coastal vegetation habitats (Bolgova, 1996; Berezenko \& Povoroznyuk, 2012; Litvinskaya, 2013). Previously, the ecological and social importance of the Sudzhuk Lagoon was associated with reserves of therapeutic muds (Frenkel, 1900). Its formation was connected with high productivity of charophytes that were dominant before the 1970s (Gromov, 1982; Kalugina-Gutnik et al., 1988; Berezenko \& Povoroznyuk, 2012). The first studies of charophytes and bottom vegetation in the Sudzhuk Lagoon were carried out at the beginning of the $20^{\text {th }}$ century by V.M. Arnoldi (1924) and K.V. Arnoldi (1924), and the research of benthic communities and water quality began in the mid-20 $0^{\text {th }}$ century (Frindlyand et al., 1957; Milovidova, 1961; Kalugina-Gutnik, 1975).
In accordance with environmental importance of the lagoon's ecosystems, in 1983 the «Sudzhuk Lagoon» Natural Monument of regional significance $\left(0.5823 \mathrm{~km}^{2}\right)$ was created, and in 2016 the «Prilagunye» Natural Recreational Sight $(0.0845$ $\mathrm{km}^{2}$ ) was established, both being included in the network of Protected Areas of the Krasnodarsky Krai (Zabelina et al., 2006; Litvinskaya, 2017). The water surface area of the «Sudzhuk Lagoon» Natural Monument was $0.356 \mathrm{~km}^{2}$ with the marine zone along the Sudzhuk Spit of about $50 \mathrm{~m}$ width. The monitoring of the macrophytobenthos of the «Sudzhuk Lagoon» Natural Monument was continuously carried out after its creation, including the study of species composition, structure of bottom vegetation, and spatial distribution of key macrophytes (Gromov, 1982; Kalugina-Gutnik et al., 1988; Bolgova, 1996).

Considering the significant shifts in the hydrological and hydrochemical regime that occurred in recent decades, the goal of the present research was to summarise the macrophytobenthos longterm monitoring data of the Sudzhuk Lagoon and 
identify the changes in the communities structure from 1921 to 2015. This research has scientific and environmental significance, since such long, regular series of bottom vegetation monitoring were scarce or absent in the Black Sea, like in many regions of the World (Milchakova, 2003; Milchakova et al., 2015), and it should be continued for lagoon ecosystems on the Caucasus coast of the Black Sea using the recommendations of the Marine Strategy Framework Directive (EPC, 2008).

\section{Material and Methods \\ Characteristics of the Sudzhuk Lagoon}

The Sudzhuk Lagoon is located at the southeast edge of the Abrau Peninsula, on the western shore of Novorossiysk Bay. The lagoon is separated from the sea by a spit 25 to $70 \mathrm{~m}$ wide at the east and connected to the Black Sea by a small channel in the southwestern part (Fig. 1). Until 1950 , the width of the channel was about $20 \mathrm{~m}$, and it did not exceed $2 \mathrm{~m}$ by 2017 . The connection of the lagoon with the Black Sea was often disturbed due to channel washout resulting from heavy storms, which were typical for the Novorossiysk Bay region (Simonova \& Altman, 1991).
The area of the lagoon was $0.38 \mathrm{~km}^{2}$ in the early $20^{\text {th }}$ century; it reduced to $0.35 \mathrm{~km}^{2}$ by 1985 , and it was about $0.33 \mathrm{~km}^{2}$ within the last decade (Berezenko \& Povoroznyuk, 2012). The average depth was about $0.85 \mathrm{~m}$, and the maximum depth did not exceed $1.5 \mathrm{~m}$ (Bolgova, 1996). The temperature and salinity presented seasonal and interannual fluctuations, and the lagoon was completely covered by ice in cold winters (Simonova \& Altman, 1991). Fresh water inflow was due mostly to atmospheric precipitation, and to a lesser degree to small streams and groundwater throughflow. In recent years, due to coastal development, the number of streams and springs has significantly decreased, and the inflow of freshwater to the lagoon has dramatically reduced. At the same time, the inflow of contaminated water in areas with a high anthropogenic load in the coastal zone has been observed (Martynov et al., 2011; Berezenko \& Povoroznyuk, 2012).

Gray mud dominated in bottom sediments (about $90 \%$ of the bottom area), and shell rock, silt sands and pebbles were less common (Bolgova, 1996). Hard rocks were typical for the central part of the western shore between seashore and $0.5 \mathrm{~m}$ depth.

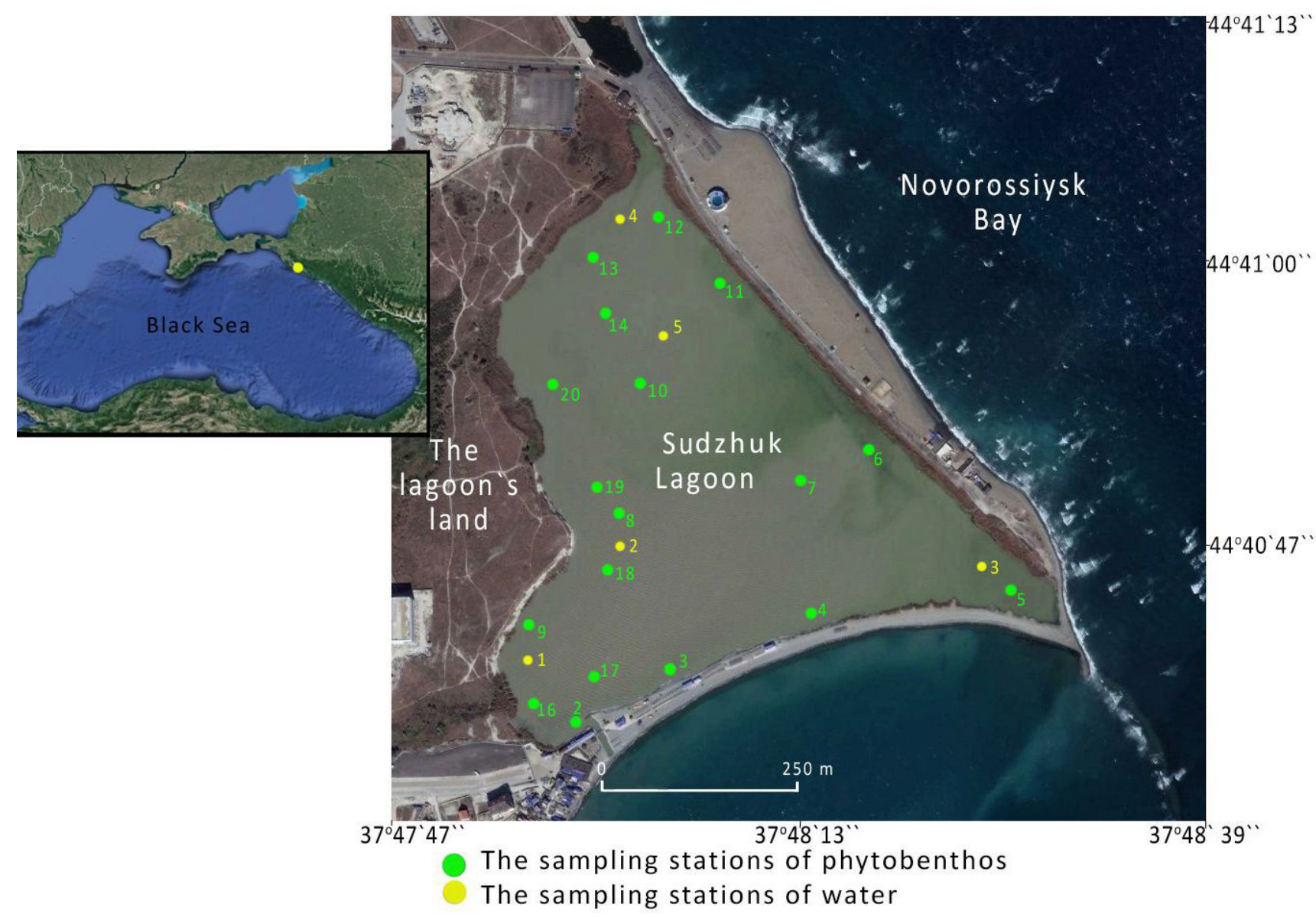

Fig. 1. Scheme of the Sudzhuk Lagoon and the sampling stations of macrophytobenthos (from 1978 to 2015). 


\section{Methods}

The macrophytes samples were taken by the authors in the summer season from 1978 to 2015, using the same permanent grid of stations (Fig. 1) which were used by Kalugina-Gutnik et al. (1988). Sampling of macrophytes was carried out using 25 $\times 25 \mathrm{~cm}$ frame in quadruplicate, placed randomly at each station (Kalugina-Gutnik, 1975). All samples were packed, labeled and stored in refrigerator bags during the field's research. In total, 216 quantitative and 72 qualitative samples of macrophytobenthos were collected and processed during the research period. The identification of macrophytes was carried out in the laboratory after sampling, and the biomass $\left(\mathrm{g} \times \mathrm{m}^{-2}\right.$, wet weight $)$ of epilithic species was measured. Macroalgae were identified using specific scientific guides (Zinova, 1967), in accordance with nomenclatural changes (Guiry \& Guiry, 2018). The communities were indicated according to the classification of bottom vegetation for the Black Sea (Kalugina-Gutnik, 1975).

The water samples from five stations in the Sudzhuk Lagoon were taken in 1985 and 2015. These sets of samples were analysed in the Chemical Laboratory of the State Maritime University (Novorossiysk) in accordance with standard procedures (Drugov \& Rodin, 2012) with the participation of N.S. Berezenko.

The ecological status of the Sudzhuk Lagoon in 2015 was assessed using the Ecological Index (EI) (Orfanidis et al., 2014) according to the Water Framework Directive (WFD). Index EI was calculated by a simplified formula as the percentage ratio of biomass (wet weight) of late-sensitive (highly sensitive) species (Ecological Status Group I, ESG I) divided by biomass of opportunistic-tolerant species (Ecological Status Group II, ESG II). In ESG I, Ruppia cirrhosa (Petagna) Grande was included. ESG II contains species mostly typical for eutrophic areas such as Ulva intestinalis L., Cladophora albida (Nees) Kützing, Lophosiphonia obscura (C. Agardh) Falkenberg, and also Stukenia pectinata (L.) Börner, due to its high tolerance to changes in environmental conditions. The percentage ratio of biomass of ESG I and ESG II species were divided in four ecological classes from $0 \%$ to $100 \%$ following the range of EI: $8-10$ (high status, the share of ESG I is between $80 \%$ and $100 \%$ ), 6-8 (good status, the share of ESG I varies from $60 \%$ to $80 \%$ ), 4-6 (moderate status, the share of ESG I varies from $40 \%$ to $60 \%$ ), and $2-4$ (poor status, the share of ESG I is between $0 \%$ and $40 \%$ ).

Analysis of variance (ANOVA) was used to determine differences between biomass of macrophytes in 1985 and 2015, and species composition from 1921 to 2015 . A test for the normality of the distribution of these indicators was carried out using the Shapiro-Wilk W-test. The differences in the biomass and species composition were estimated by the KruskalWallis test. The published data and scientific reports (unpublished data), which were provided by N.S. Beresenko, were considered for statistical analysis.

The statistical analysis was carried out using the Statistica 10 software package. The critical level of significance in checking statistical hypotheses (p) was assumed to be 0.05 .

\section{Results}

The hydrological and hydrochemical parameters of the Sudzhuk Lagoon in 1985 and 2015 are represented in Table 1.

The salinity ranged from $18.7 \%$ to $19.8 \%$ and between $17.0 \%$ and $18.9 \%$ in 1985 and 2015, respectively (Table 1). The highest salinity was found near the channel in 2015 (station 1) and in the shallow areas in 1985 (station 2 and station 4). From 1985 to 2015, the nitrites concentration increased 8.2 times at station 1, 1.2 times at station 2 and 6.5 times at station 4 . The nitrites content was lower in 2015 at station 5, and it varied insignificantly at station 3 . The phosphates concentration varied slightly at station 2 and station 3 . It increased over 1.4 times at station 1 and decreased 2.2 times at station 4. An increase in the petroleum hydrocarbons concentration was recorded at all stations; it was 18.4 times at station 1, and 2.7-3.2 times at other sites. In general, the highest content of nutrients and petroleum hydrocarbons was noted in 2015 near the channel at station 1 (Table 1).

\section{Changes in macrophyte species composition}

In total, 49 species of macrophytes were identified from 1921 to 2015: four species of Tracheophyta, three - Charophyta, 18 - Chlorophyta, seven - Ochrophyta and 17 - Rhodophyta species. Until 1975, the constant species were Chara vulgaris L., Lamprothamnium papulosum (K. Wallroth) J. Groves, Zostera marina L., Stuckenia pectinata, Ceramium virgatum Roth, Cladophora albida and Lophosiphonia obscura.

From 1921 to 2009, the number of macrophytes species remained constant, while it nearly doubled from 1995 to 2015, mainly due to Chlorophyta species (Table 2). For the last two decades the share of Ochrophyta species within the macroalgae richness decreased from $25 \%$ to $8 \%$, and the share of Chlorophyta species increased from $41.7 \%$ to $56 \%$. 
Table 1. Interannual changes of hydrological and hydrochemical parameters in the Sudzhuk Lagoon (depth $0.5 \mathrm{~m}$, June - July, in 1985 and 2015)

\begin{tabular}{|c|c|c|c|c|c|c|}
\hline Station & Salinity, \%o & Oxygen content & Oxygen & \multicolumn{2}{|c|}{ Content of nutrients, $\mu \mathrm{mol} / \mathrm{l}$} & \multirow{2}{*}{ Petroleum } \\
\cline { 5 - 6 } & & $\mathrm{O}_{2}, \mathrm{mg} / \mathrm{l}$ & saturation, \% & $\mathrm{NO}_{2}$ & $\mathrm{PO}_{4}$ & hydrocarbons, $\mathrm{mg} / 1$ \\
\hline Station 1 & $18.8 / 18.9$ & $8.69 / 7.73$ & $96.3 / 85.7$ & $1.41 / 11.63$ & $3.47 / 4.79$ & $<0.01 / 0.18$ \\
\hline Station 2 & $19.3 / 18.0$ & $8.40 / 7.84$ & $93.1 / 86.9$ & $3.48 / 4.13$ & $4.95 / 3.83$ & $-/ 0.04$ \\
\hline Station 3 & $18.9 / 17.8$ & $8.10 / 5.74$ & $89.8 / 63.6$ & $2.50 / 2.17$ & $3.74 / 4.20$ & $0.02 / 0.04$ \\
\hline Station 4 & $19.8 / 18.6$ & $8.68 / 7.17$ & $96.2 / 79.5$ & $1.52 / 9.87$ & $2.79 / 1.26$ & $-/ 0.09$ \\
\hline Station 5 & $18.7 / 17.0$ & $8.68 / 8.73$ & $96.2 / 96.8$ & $3.59 / 3.35$ & $5.58 / 4.19$ & $<0.01 / 0.03$ \\
\hline
\end{tabular}

Note: the number of stations is the same as in Fig. 1; before the slash the data from 1985 (Kalugina-Gutnik et al., 1988); after the slash the data from 2015, which were provided N.S. Berezenko and A.M. Stikhova; a dash - the content is absent.

Table 2. Changes in the number of macrophytes species in the Sudzhuk Lagoon from 1921 to 2015

\begin{tabular}{|c|c|c|c|c|c|c|c|c|}
\hline \multirow{2}{*}{ Taxon } & \multicolumn{9}{|c|}{ Number of species } \\
\cline { 2 - 10 } & 1921 & 1970 & 1979 & 1985 & 1995 & 2009 & 2012 & 2015 \\
\hline Tracheophyta & 4 & 2 & 2 & 2 & 2 & 1 & 2 & 2 \\
\hline Charophyta & 2 & 2 & 2 & 2 & - & 1 & 2 & 2 \\
\hline Chlorophyta & - & 3 & 3 & 8 & 5 & 11 & 11 & 14 \\
\hline Ochrophyta & 2 & 3 & 3 & 1 & 3 & - & 2 & 2 \\
\hline Rhodophyta & 8 & 6 & 6 & 4 & 4 & 5 & 6 & 7 \\
\hline Total number of species & 16 & 16 & 16 & 17 & 14 & 18 & 23 & 27 \\
\hline
\end{tabular}

Note: a dash indicates the absence of species.

Although the number of macrophytes changed insignificantly from 1921 to 1995 , typical species of charophytes (Chara vulgaris and Lamprothamnium papulosum) disappeared, and typical marine species of Ochrophyta were found, including Cystoseira barbata (Stackhouse) C. Agardh and Cladostephus spongiosum f. verticillatum (Lightfoot) Prud'homme van Reine. In 2015 six new species were observed, among them three species of Chlorophyta (Ulothrix tenerrima (Kützing) Kützing, Cladophora laetevirens (Dillwyn) Kützing, Percursaria percursa (C. Agardh) Rosenvinge), two species of Rhodophyta (Chroodactylon ornatum (C. Agardh) Basson, Acrochaetium secundatum (Lyngbye) Nägel), and one species of Ochrophyta (Feldmannia irregularis (Kützing) Hamel). At the same time, many typical species had disappeared from 1995 to 2015, among them two Tracheophyta species (Zostera marina and Ruppia maritima L.), two Ochrophyta species ( $C$. barbata and Dictyota repens J. Agardh) and five Rhodophyta species (Ceramium ciliatum (J. Ellis) Ducluzeau, Dasya baillouviana (S.G. Gmelin) Montagne, Polysiphonia opaca (C. Agardh) Moris \& De Notaris, P. pulvinata (Roth) Sprengel and Vertebrata fucoides (Hudson) Kuntze).

\section{Changes in bottom vegetation}

Significant changes of the macrophytobenthos were observed from 1985 to 2015 (Fig. 2, 3). Although its average biomass decreased slightly in 2015 (from 1198 to $1032 \mathrm{~g} \times \mathrm{m}^{-2}$ ), the biomass of macrophytes by stations (Fig. 2) varied widely (from 168 to $1813 \mathrm{~g} \times \mathrm{m}^{-2}$ ), showing a reducing trend almost everywhere (except stations 2, 5, 9, and station 16). The lowest biomass of macrophytes was recorded near the channel at station 2 and station 17 in both 1985 and 2015. Dramatic changes were observed in the charophyte communities (Lamprothamnium papulosum and Chara vulgaris) and vascular plants (Ruppia cirrhosa, $R$. maritima and Zostera marina). In 1985, the biomass of Ch. vulgaris ranged from 1.2 to $16 \mathrm{~g} \times \mathrm{m}^{-2}$, and in 2015 it did not exceed $1.2-4.4 \mathrm{~g} \times \mathrm{m}^{-2}$. In 2015, L. papulosum was noted only in the northern part of the Sudzhuk Lagoon, whereas this species had dominated everywhere by the mid- $20^{\text {th }}$ century.

The Ruppia cirrhosa-Lophosiphonia obscura - Cladophora albida communities dominated at all sites during recent decades. Although the average biomass of $R$. cirrhosa decreased insignificantly from 1985 to 2015 (between $294.3 \mathrm{~g} \times \mathrm{m}^{-2}$ and

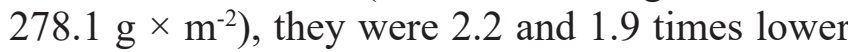
near the channel (stations $2,3,17$ ) and in the northern part (stations 12,13), respectively. The average biomass of L. obscura was also reduced (from 570.8 $\mathrm{g} \times \mathrm{m}^{-2}$ to $492.4 \mathrm{~g} \times \mathrm{m}^{-2}$ ), and it varied widely by stations (between $44.8 \mathrm{~g} \times \mathrm{m}^{-2}$ and $1318.4 \mathrm{~g} \times \mathrm{m}^{-2}$ ). The increase of $R$. cirrhosa biomass was $1.5-2.5$ times only in the southeastern part (stations 5-7), and the share of L. obscura in the biomass of communities was the highest near the channel and also in the southeastern part, where it reached $82.2 \%$ and $72.7 \%$, respectively. 


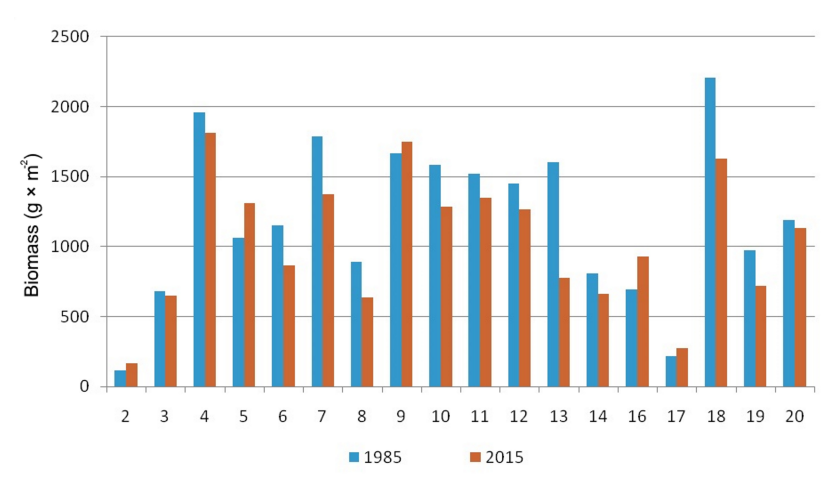

Fig. 2. Changes in biomass $\left(\mathrm{g} \times \mathrm{m}^{-2}\right)$ of macrophytobenthos in the Sudzhuk Lagoon by stations (from 2 to 20) in summer 1985 and 2015.

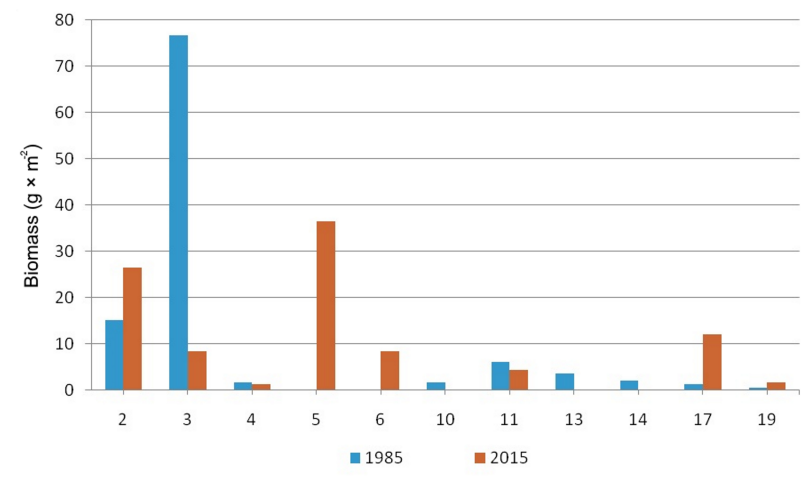

Fig. 3. Changes of biomass $\left(\mathrm{g} \times \mathrm{m}^{-2}\right)$ of Ulva intestinalis by stations in the Sudzhuk Lagoon in summer 1985 and 2015.

The most significant changes were registered for the biomass of Chlorophyta species in the shallow areas of the Sudzhuk Lagoon from 1985 to 2015 (Fig. 3). The biomass of Ulva intestinalis increased in the southwestern part (stations $2,17,19$ ) from $1.2 \mathrm{~g} \times \mathrm{m}^{-2}$ to $26.4 \mathrm{~g} \times \mathrm{m}^{-2}$; whereas it decreased in the southeastern area (station 3) from $76.8 \mathrm{~g} \times \mathrm{m}^{-2}$ to $8.4 \mathrm{~g} \times \mathrm{m}^{-2}$. A high abundance of $U$. intestinalis was found near the spit in the eastern part, where it was previously absent, and its biomass varied from

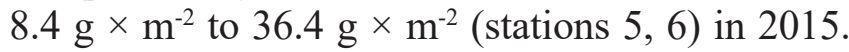
With the development of $U$. intestinalis, the biomass of Cladophora albida decreased by more than an order of magnitude (from $834 \mathrm{~g} \times \mathrm{m}^{-2}$ to $82.4 \mathrm{~g} \times$ $\mathrm{m}^{-2}$ ) at many sites.

A degradation of the macroalgae communities was identified in the northern part of the Sudzhuk Lagoon (stations 12,13), where intensive overgrowth of vascular plants, marsh and near-water vegetation was observed, with a dominance of Phragmites australis (Cav.) Trin ex Steud. and Stuckenia pectinata communities. These communities almost replaced the macroalgae communities.

According to the variance analysis ANOVA, a high statistical significance of difference in the macrophytes species composition from 1921 to $2015(\mathrm{p}=0.002)$ and in the average biomass of macrophytes by stations in $2015(\mathrm{p}=0.0169)$ were confirmed. At the same time, there was no significant difference in the average biomass of macrophytes by stations in 1985 and $2015(\mathrm{p}=0.3267)$.

\section{Discussion}

The Sudzhuk Lagoon belongs to C1.5 Permanent inland saline and brackish lakes, ponds and pools (EUNIS Habitats classification, 2007), and to C1.521 Submerged macrophyte communities of inland saline and brackish waters by the Black Sea classification (Minicheva et al., 2008). These habitats have a high conservation statute, since their biodiversity has dramatically decreased since the 1950 's in many coastal lagoons in Europe due to anthropogenic load and pollution (De Wit, 2011).

Similar negative changes were found in the bottom vegetation of the Sudzhuk Lagoon during the last decades. At the beginning of the $20^{\text {th }}$ century, Charophyta species (Lamprothamnium papulosum and Chara vulgaris) were dominant among the macrophytes by biomass, and Chlorophyta species were absent (Arnoldi K.V., 1924; Arnoldi V.M., 1924). In 2015, the number of Chlorophyta reached 14 species, and charophytes almost disappeared, including L. papulosum, which was included in the Red Data Book of the Russian Federation (Bardunov \& Novikov, 2008). Most of the new green macroalgae were indicators of medium or high levels of pollution from the sewage (KaluginaGutnik, 1975; Kalugina-Gutnik et al., 1988).

The charophyte (Lamprothamnium papulosum and Chara vulgaris) and seagrass (Ruppia cirrhosa, R. maritima and Zostera marina) communities were dominated until the 1980s in the Sudzhuk Lagoon; the biomass of Lamprothamnium papulosum + Chara vulgaris community varied from $550 \mathrm{~g} \times \mathrm{m}^{-2}$ to 2720 $\mathrm{g} \times \mathrm{m}^{-2}$ (Kalugina-Gutnik, 1975). In the last several decades, a significant decrease in the area occupied by charophytes $L$. papulosum and Ch. vulgaris was observed (Milovidova, 1961; Kalugina-Gutnik, 1975; Kalugina-Gutnik et al., 1988), and in 2015 Ch. vulgaris was very rarely found. Lamprothamnium papulosum, typical for clean, unpolluted water probably cannot compete with dense tufts of filamentous algae such as $U$. intestinalis that develop with nutrient enrichment. Reduction of L. papulosum and other species of charophytes were recorded along with anthropogenic induced eutrophication in saline lagoons in Denmark, Sweden and Norway (Becker et al., 2016).

The Ruppia cirrhosa - Lophosiphonia obscura-Cladophora albida communities were typical only in the early $20^{\text {th }}$ century (Arnoldi K.V., 1924; 
Arnoldi V.M., 1924), and it dominated again over the entire area in 2015. Additionally, Stuckenia pectinata, which practically disappeared by the mid-20 $0^{\text {th }}$ century (Kalugina-Gutnik et al., 1988), has occurred again in the northern and southwestern parts of the Sudzhuk Lagoon. The area of $S$. pectinata increased more than threefold in 2015 compared with 1985. According to Orfanidis et al. (2014), Stuckenia spp. are similar to opportunistic species, since they are very tolerant to salinity and their surface-to-volume $(\mathrm{S} / \mathrm{V})$ ratio is the highest, as compared to perennial seagrass and some macroalgae species.

The high abundance of Ruppia cirrhosa and Stuckenia pectinata were also probably connected with the difference in salinity in the central part of the Sudzhuk Lagoon and along its borders (Table 1). De Wit (2011) noted the homogenous salinity in the centre of coastal lagoons of Europe and the fluctuating salinity gradients along their borders. Besides, $R$. cirrhosa from the Eurasian southern seas, including the Black sea coastal lagoons and gulfs, was tole-rant to a high range of salinity up to hypersaline conditions (Milchakova, 2003, 2011). Davison \& Hughes (1998) also noted that Ruppia spp. were less sensitive to a higher content of nutrients than Zostera marina and $Z$. noltei Hornemann. The growth of $R$. cirrhosa in the polluted areas of the Sudzhuk Lagoon was probably connected with its higher tole-rance to environmental conditions, and with the reduction of the $Z$. marina and $Z$. noltei density.

The changes in macrophyte species richness, the disappearance of Ochrophyta and Charophyta species which are indicators of environmental quality, and the appearance of Chlorophyta species which are mostly typical for polluted water, were associated with a hydrological and hydrochemical regime shift and with the destruction of biotopes due to increased anthropogenic load (Martynov et al., 2011; Afanasyev et al., 2012; Berezenko \& Povoroznyuk, 2012; Litvinskaya, 2013). The same negative changes were shown for some coastal lagoons of Brazil, where the development of opportunistic species and dominance of green and red macroalgae were registered with increasing eutrophication (Amaral et al., 2018). Over the last 25 years, the decrease in macrophyte richness by $26-46 \%$ and the biomass of macrophytes by $50-72 \%$ in the average high-salinity and low-salinity lagoons, respectively, were observed (Amaral et al., 2018).

The values of EI show that almost all areas of the Sudzhuk Lagoon are in poor ecological condition, except for the central (station 10) and southeastern (stations 5-7) areas, which were at moderate status (Table 3 ). In the western part the moderate status was at stations 8 and 18 from 0.8 $\mathrm{m}$ to $1.2 \mathrm{~m}$ depth, respectively. The lowest value of EI was near the channel in the southwestern and northeastern parts (in total at 12 stations) where the highest anthropogenic and recreational load at the coastal zone (Fig. 1) and a higher content of nutrients (Table 1, stations 1,4) were observed.

Due to unplanned urbanisation of the coastal area, the threats to the natural complexes of the «Sudzhuk Lagoon» Natural Monument, including «Prilagunye» Natural Recreational Sight, are connected with the absence of associated infrastructure, and parking of motor vehicles in the marine protection zone, leading to littering and eutrophication of the shallow area (Martynov et al., 2011; Afanasyev et al., 2012; Berezenko \& Povoroznyuk, 2012). In many areas of the Sudzhuk Lagoon, the destruction of macrophyte biotopes was recorded due to bottom clearance for recreational use, including the removal of therapeutic mud that lost its properties many decades ago due to eutrophication. An increase in anthropogenic pressure on the Sudzhuk Lagoon and the inflow of domestic wastewater will lead to more pronounced changes in bottom vegetation, including swamping by $P h$. australis, which was capable of growing in waters with $10-15 \%$ salinity or more, and often formed extensive stands in the borders of the coastal lagoons where freshwater inflow was observed (De Wit, 2011).

Table 3. The ecological status of the Sudzhuk Lagoon locations by the EI value

\begin{tabular}{|c|c|c|c|c|}
\hline Location & Number of stations & $\begin{array}{c}\text { ESG I } \\
\text { (share of biomass, \%)* }\end{array}$ & $\begin{array}{c}\text { ESG II } \\
\text { (share of biomass, \%) }\end{array}$ & Ecological status \\
\hline Southwest, near channel & $2,3,4,16,17$ & $3.2-12.4$ & $87.6-96.8$ & poor \\
\hline West & $8,9,18,19,20$ & $20.1-54.2$ & $45.8-79.9$ & $\begin{array}{c}\text { poor (stations 9, 19, 20), } \\
\text { moderate (stations 8, 18) }\end{array}$ \\
\hline Centre & 10 & 41.6 & 58.4 & moderate \\
\hline Northeast & $11,12,13,14$ & $6.8-31.6$ & $68.4-93.2$ & poor \\
\hline Southeast & $5,6,7$ & $40.0-51.8$ & $48.2-60.0$ & moderate \\
\hline
\end{tabular}

Note: number of stations is identical to Fig. 1; * - share of biomass ESG I and ESG II was calculated from the total biomass of each station. 
The lack of effective measures to protect the «Sudzhuk Lagoon» Natural Monument can lead to the loss of this unique ecosystem. We recommend the creation of a «Sudzhuk Lagoon» Sanctuary by combining the «Sudzhuk Lagoon» Natural Monument and «Prilagunye» Natural Recreational Sight, due to the 13 species of vascular plants, including Lamprothamnium papulosum, listed in the Red Data Book of the Russian Federation (Bardunov \& Novikov, 2008), the 19 macrophytes and vascular plants included in the Red Data Book of the Krasnodarsky Krai (Litvinskaya, 2017), and to the 8 species of birds having an international conservation status (Litvinskaya, 2013). The development of a system of specially protected natural areas, including the Black Sea, was justified in the Environmental Policy of the Russian Federation until 2030. In our opinion, the conservation measures of these natural protected areas, including the coastal lagoons, should take into account their conservation (EUNIS Habitats classification, 2007; IUCN, 2016) and ecological status using the state of macrophytes communities as a quality element of WFD.

\section{Conclusions}

In accordance with the almost 100-year period of investigation of the Sudzhuk Lagoon macrophytobenthos state, the changes in the species richness and structure of their communities were identified. The number of macrophytes increased from 16 to 27 between 1921 and 2015, mainly due to the development of Chlorophyta species. In the last several decades, the typical species Dictyota repens, Ceramium ciliatum, Dasya baillouviana, Polysiphonia opaca, P. pulvinata, Vertebrata fucoides, and Zostera marina disappeared, while the abundance of Ulva intestinalis and other opportunistic species, considered as indicators of eutrophication and pollution, substantially increased.

The creation of the «Sudzhuk Lagoon» Natural Monument in 1983 did not stop the negative changes in the bottom vegetation. Significant changes of the community structure were found from 1985 to 2015. The largest areas of the Sudzhuk Lagoon were occupied by the Ruppia cirrhosa-Lophosiphonia obscura-Cladophora albida community with a dominance of $R$. cirrhosa. The communities of seagrasses (Zostera marina and Z. noltei), charophytes (Chara vulgaris and Lamprothamnium papulosum), which previously dominated, had almost disappeared. The biomass of charophytes Ch. vulgaris and
L. papulosum decreased by more than two orders of magnitude. The communities of vascular plants and marsh vegetation with a dominance of Phragmites australis and Stuckenia pectinata replaced the communities of macroalgae, especially in the northern part of the Sudzhuk Lagoon. Almost all research areas of the Sudzhuk Lagoon are in a poor ecological status, except central and southeastern parts, found in the moderate status.

It is necessary to create the «Sudzhuk Lagoon» Sanctuary by combining the «Sudzhuk Lagoon» Natural Monument and «Prilagunye» Natural Recreational Sight, and a management plan for the conservation of this unique ecosystem.

\section{Acknowledgments}

The research was carried out in accordance with the state scientific task of Admiral F.F. Ushakov State Maritime University on the topic «Environmental problems of sea transport in the South of Russia» (2016-2020), No. IKBBS AAAAB16-216022570173-6); and the A.O. Kovalevsky Institute of Marine Biological Research of RAS (IMBR) on the topic «Regularities of formation and anthropogenic transformation of biodiversity and bioresources of the Azov-Black Sea basin and other regions of the World Ocean» (No. AAAAA18-118020890074-2). Thanks are due to Prof. V.A. Turkin, Head of the Department «Technospheric Security in Transport» of Admiral F.F. Ushakov State Maritime University, for the organisation of field research, to Dr. A.M. Stikhova, from the same Department of Admiral F.F. Ushakov State Maritime University for help with the processing of water samples, and to Kathleen Parsons (UK, retired) for checking the English translation.

\section{References}

Afanasyev D.F., Sereda M.M., Berezenko N.S., Martynov Ya.I. 2012. Macrophytobenthos of the nature monument «Sudzhuk Lagoon» of Novorossiysk Bay. Proceedings of the Nature Reserve "Cape Martyan» 3: 166-176. [In Russian]

Amaral H.B.F., Reis R.P., de Oliveira Figueiredo M.A., de Gusmão Pedrini A. 2018. Decadal shifts in macroalgae assemblages in impacted urban lagoons in Brazil. Ecological Indicators 85: 869-877. DOI: 10.1016/j.ecolind.2017.11.055

Arnoldi K.V. 1924. Distribution of vegetation in the Sudzhuk Lagoon. Proceedings of the Russian Hydrological Institute 10: 61-70. [In Russian]

Arnoldi V.M. 1924. Algae of the Sudzhuk Lagoon (near Novorossiysk). Proceedings of the Russian Hydrological Institute 10: 42-56. [In Russian]

Bardunov L.V., Novikov V.S. (Eds.). 2008. Red Data Book of the Russian Federation. Plants and Fungi. Moscow: Fellowship of Scientific Publications KMK. 885 p. [In Russian]

Becker R., Blindow I., Doege A., Franke T., Gregor T., Hamann U., Jäger D., Jorda C., Kabus T., Korsch 
H., Korte E., Kusber W.-H., Pätzold F., Raabe U., Schubert H., Teppke M., van de Weyer K., Wolff P. 2016. Beschreibung der Characeen-Arten Deutschlands. Armleuchteralgen - Die Characeen Deutschlands. Berlin: Heidelberg. 572 p. DOI: 10.1007/9783-662-47797-7

Berezenko N.S., Povoroznyuk A.T. 2012. About the changes in the species composition of the macrophytobenthos in the Sudzhuk lagoon over the past 40 years (1970-2012). Fundamental Research 9(4): 787-791. [In Russian]

Bolgova L.V. (Cond.). 1996. The Sudzhuk Lagoon - a Nature Monument (based on hydrochemical, hydrobiological and botanical research). The Scientific Report. Final Part. Novorossiysk: Novorossiysk biological station. 81 p. [In Russian]

Davison D.M., Hughes D.J. 1998. Zostera biotopes. An overview of dynamics and sensitivity characteristics for conservation management of marine SACs. Vol. 1. Scottish Association for Marine Sciences; UK Marine SACs Project. 95 p.

De Wit R. 2011. Biodiversity of coastal lagoon ecosystems and their vulnerability to global change. In: O. Grillo, G. Venora (Eds.): Ecosystems Biodiversity. IntechOpen Publisher. P. 29-40. DOI: 10.5772/24995

Drugov Yu.S., Rodin A.A. 2012. Analysis of contaminated water: practical guidance. Moscow: BINOM. Laboratoriya znaniy. 684 p. [In Russian]

EPC. 2008. European Parliament Council. Directive 2008/56/EC of the European Parliament and of the Council of 17 June 2008 Establishing a framework for community action in the field of marine environmental policy (Marine Strategy Framework Directive). Available from: http://ec.europa.eu/environment/marine/ good-environmental-status/index_en.htm

EUNIS Habitats classification. 2007. EUNIS, the European Nature Information System. Available from http://www. eunis.eea.europa.eu/

Frenkel I.A. 1900. Novorossiysk Estuary Lake. In: Proceedings of the First All-Russian Congress by climatology, hydrology and balneology. Vol. 2. St. Petersburg. P. 616-633. [In Russian]

Frindlyand I.G., Kryshta E.G., Dvurechenskaya A.A. 1957. Some data on the ichthyofauna of the Sudzhuk Lagoon. Proceedings of the Novorossiysk biological station 1: 69-75. [In Russian]

Gromov V.V. 1982. Ecological and phytocoenotic changes in the Sudzhuk Lagoon. Proceedings of the North Caucasian Scientific Centre of High School. Natural Sciences 4(37): 45-48. [In Russian]

Guiry M.D., Guiry G.M. 2018. AlgaeBase. World-wide electronic publication. Galway: National University of Ireland. Available from http://www.algaebase.org

IUCN. 2016. Guidelines for the application of IUCN Red List of Ecosystems Categories and Criteria. Version
1.0. Gland, Switzerland: International Union for Conservation of Nature (IUCN). 93 p.

Kalugina-Gutnik A.A. 1975. Phytobenthos of the Black Sea. Kiev: Naukova Dumka. 248 p. [In Russian]

Kalugina-Gutnik A.A., Khalilova M.R., Mironova N.V., Berezenko N.S. 1988. The current state of phytobenthos in Sudzhuk Lagoon. Ekologiya morya 30: 29-36. [In Russian]

Litvinskaya S.A. 2013. Modern system of Nature Reserves of the Western Caucasus and their problems. Bulletin SNBG 108: 8-20. [In Russian]

Litvinskaya S.A. (Ed.). 2017. Red Data Book of the Krasnodarsky Krai. Plants and Fungi. Krasnodar: Administration of the Krasnodarsky Krai. 850 p. [In Russian]

Martynov Ya.I., Afanasyev D.F., Berezenko N.S. 2011. The current state of phytobenthos of the Sudzhuk Lagoon of Novorossiysk Bay and its long-term dynamics. In: Proceedings of the International Scientific-Practical Conference «Actual problems of biology, nanotechnology and medicine». P. 32-34. [In Russian]

Milchakova N.A. 2003. The seagrasses of the Black, Azov, Caspian and Aral Seas. In: E.P. Green, F.T. Short (Eds.): World Atlas of Seagrasses. Chapter 4. Berkeley, University of California Press. P. 59-64.

Milchakova N.A. 2011. Marine plants of the Black Sea. An illustrated field guide. Sevastopol: DigiPrint Press. 144 p.

Milchakova N.A., Alexandrov V.V., Bondareva L.V., Pankeeva T.V., Chernysheva E.B. 2015. Marine Protected Areas of the Crimea. Scientific Handbook. Simferopol: N. Oreanda. 312 p. [In Russian]

Milovidova N.Yu. 1961. Hydrobiological characteristics of the Sudzhuk Lagoon. Proceedings of the Novorossiysk biological station 14: 69-80. [In Russian]

Minicheva G., Maximova O., Moruchkova N., Simakova U., Sburlea A., Dencheva K., Aktan Y., Sezgin M. 2008. State of the macrophytobenthos. In: State of the Environment of the Black Sea (2001-2006/7). Istanbul: Referans Çeviri Hizmetleri, Yazılım ve Yayıncılık Ltd. P. 218-242.

Orfanidis S., Dencheva K., Nakou K., Tsioli S., Papathanasiou V., Rosati I. 2014. Benthic macrophyte metrics as bioindicators of water quality: towards overcoming typological boundaries and methodological tradition in Mediterranean and Black Seas. Hydrobiologia 740(1): 61-78. DOI: 10.1007/s10750-014-1938-x

Simonova A.I., Altman E.N. (Eds.). 1991. Hydrometeorology and hydrochemistry of the USSR seas. Vol. 4. Black Sea. Issue 1: Hydrometeorological conditions. St. Petersburg: Gidrometeoizdat. 429 p. [In Russian]

Zabelina N.M., Issaeva-Petrova L.S., Korotkov V.N., Nazyrova R.I., Onufrenja I.A., Otchagov D.M., Potapova N.A. 2006. Marine and coastal Protected Areas of Russia. Moscow: ARRINP. 72 p. [In Russian]

Zinova A.D. 1967. The guidebook for green, brown and red algae of the southern seas of the USSR. Leningrad: Nauka. 397 p. [In Russian] 


\title{
МНОГОЛЕТНИЕ ИЗМЕНЕНИЯ МАКРОФИТОБЕНТОСА ПАМЯТНИКА ПРИРОДЫ «СУДЖУКСКАЯ ЛАГУНА» (ЧЕРНОЕ МОРЕ)
}

\author{
Н. С. Березенко ${ }^{1}$, Н. А. Мильчакова² \\ ${ }^{1}$ Государственный морской университет имени адмирала Ф.Ф. Ушакова, Россия \\ e-mail: n-berezenko6753@rambler.ru \\ ${ }^{2}$ Институт морских биологических исследований имени А.О. Ковалевского РАН, Россия \\ e-mail:milchakova@gmail.com
}

\begin{abstract}
Суджукская лагуна, включая Суджукскую косу и прилегающую территорию, представляет собой уникальный природный комплекс северо-восточной части Черного моря, который изучается на протяжении последнего столетия. В соответствии с экологической значимостью лагунных экосистем, в 1983 г. был создан памятник природы регионального значения «Суджукская лагуна», входящий в экологическую сеть ООПТ Краснодарского края. Цель настоящего исследования заключалась в выявлении многолетних изменений донной растительности лагуны с 1921 по 2015 гг., в том числе видового состава и структуры фитоценозов. Показано, что за сравниваемый период количество видов макрофитов увеличилось с 16 до 27. При этом исчезло более десяти типичных видов и появилось пять новых видов, характерных для эвтрофных акваторий. Несмотря на создание памятника природы, в составе макрофитобентоса зафиксировано почти полное исчезновение типичного ранее фитоценоза харовых водорослей Lamprothamnium papulosum + Chara vulgaris и доминирование на многих участках фитоценоза Ruppia cirrhosa-Lophosiphonia obscura - Cladophora albida. К 2015 г. биомасса зеленой водоросли Ulva intestinalis (вида-оппортуниста) вблизи канала, соединяющего лагуну с морем, увеличилась на порядок по сравнению с 1985 г. В последние годы значительная трансформация отмечена также в сообществах прибрежной водной растительности, в их составе обнаружено преобладание Phragmites australis и Stuckenia pectinata. В соответствии с экологическим индексом (ЕI), почти все районы лагуны характеризуются низким экологическим статусом. Лишь для некоторых участков центрального и юго-восточного районов отмечен умеренный экологический статус. При отсутствии менеджемент-плана по сохранению Суджукской лагуны, негативном воздействии природных и антропогенных факторов, в том числе нерегулируемой рекреации, может произойти утрата уникального природного комплекса. Предложены эффективные меры, направленные на восстановление экосистемы Суджукской лагуны, ее биологического и ландшафтного разнообразия.
\end{abstract}

Ключевые слова: Charophyta, биомасса, видовой состав, макрофиты, многолетний мониторинг, экологический статус 